\title{
HEALING AND PSYCHOTHERAPY MODEL THROUGH THE EMOTIONAL-SPIRITUAL POWER: A CASE STUDY OF PRISONERS IN SEMARANG
}

\author{
TAUFIQ HIDAYAT ${ }^{1}$ \\ Universitas Islam Negeri Walisongo Semarang
}

\section{Abstract}

Stress and depression are two common problems experienced by prisoners. These two problems are even able to lead to new problems, such as a fight between prisoners, drug trafficking, sexual abuse, and suicide. A new approach addressing those problems is required, one of which is through the development of emotional and spiritual awareness. Using mix-method and quasi-experimental design, this study focuses on how to increase emotional and spiritual awareness of the prisoners in Semarang who have joined a healing and psychotherapy program named Emotional-Spiritual Power (ESP). Through experimental analysis with $\mathrm{T}_{\text {tes }}$ and descriptive analysis, the study found that the ESP program is influential in enhancing the prisoner's emotional and spiritual awareness significantly. The program helps them transform into a new person with positive energy in the mind, heart, and behavior. This way, all the internal problems that reside within the prisoners, such as stress and depression, can be cured.

Stres dan depresi seringkali dialami oleh narapidana, sehingga banyak terjadi perkelahian antar narapidana, pengedaran narkoba, pelecehan seksual, dan juga bunuh diri. Diperlukan model-model baru dalam menangani masalah ini, salah satunya dengan pengembangan kesadaran emosi dan spiritual. Dengan menggunakan mix-method dan quasi experimental design, penelitian ini

Corresponding author; email: ${ }^{1}$ taufiqhidayatlp@gmail.com.

ISSN 0852-7172 (p) 2461-064X (e)

(C) 2018 Walisongo: Jurnal Penelitian Sosial Keagamaan

http://journal.walisongo.ac.id/index.php/walisongo 
fokus pada bagaimana peningkatan kesadaran emosi dan spiritualitas para narapidana di Semarang yang telah mengikuti program pelatihan Emotional Spiritual Power (ESP). Melalui analisis eksperimen dengan $T_{\text {tes }}$ dan analisis deskriptif, penelitian ini menemukan bahwa pada narapidana yang telah mengikuti program pelatihan ESP mengalami peningkatan kesadaran emosi dan spiritual secara signifikan. Dengan peningkatan tersebut menjadikan para narapidana menjadi pribadi baru yang penuh energi positif dan dekat dengan Allah swt., baik secara pikiran, hati, dan perilaku kehidupan sehari-hari, sehingga segala penyakit hati, seperti setres dan depresi para narapidana, dapat disembuhkan.

Keywords: depression; Emotional Spiritual Power; healing; prisoners; psychotherapy.

\section{Introduction}

Prisoners are very susceptible to stress and depression in prison. This is because the prisoners face new and different condition while in the prison. Their past life before becoming prisoners were often the burden of thought. Fear of facing life in prisons and in their return to normal life outside prisons also clung heart and mind. This condition causes stress and depression, leading to fights between prisoners, drug trafficking, sexual abuse, and suicide. Stress and depression experienced by prisoners can lead to a heavier burden of life. Therefore, the existence of prisons in fact aims to restore the positive nature of prisoners at life as a form of guidance for those who have committed criminal acts. However, in reality, their life in prisons is not necessarily able to make them better. They may even get worse because of the influence of life in prisons.

In this context the question arises, why does training in prisons in a certain time not make the prisoners' behavior for the better? Even the criminal act can still be done in prisons, and then after going out of prisons they still repeat criminal acts that 
have ever been done before. This case shows that the guidance in prisons is not necessarily able to make the prisoners become aware of and improve themselves. Instead, the prisoners receive "training" or technique in committing crimes when they meet other prisoners. In other cases, many prisoners are actually getting threats and blackmail, causing them to experience fear, anxiety, and make them productive.

The next question should be asked: how is coaching model conducted in prisons so far? Does it touch the human nature covering both the spiritual and physical aspects? The importance of considering the psychological aspects of prisoners due to crime or other crimes may arise as a result of the shutting of the heart from the path of truth. The shutting of the heart may eventually causes "heart disease". The one type of heart disease is hasud 'envy/ jealousy'; that is one does not like to see others' advance or succeed, nammam or pitting, conceited (arrogant) demeaning others, feel the greatest, ' $u j u b$ 'proud of the self', and so on (Syukur and Usman 2009).

Heart disease can then lead to the onset of mental illness. Mental illness can cause mental balance disorders. Impaired mental balance ultimately affects body chemistry imbalances. This imbalance can cause symptoms of other diseases called psychosomatic. Therefore, it is necessary that a comprehensive treatment, not only the physical aspects of prisoners but also psychological aspect, is very important to be able to realize the pattern changes (behavior) towards a new, more positive pattern.

As a human being, prisoners have two inseparable elements, i.e. physical/body and spiritual/soul. Quoted from Van Peursen, physical and spiritual aspects have blended so unified, so that one single unit cannot be separated from the other. Each of these elements has different needs and must be met, namely the 
physical or material needs are physical and spiritual needs of the non-physical (Nurulaen 2012). Prisoners require steps to neutralize or grounding, which is a method of neutralizing a process of purification of the soul effects-tazkiyat al-nafs-whether physical, emotional, spiritual and social for leading a healthy life. This method can be done with training to manage the hearts and be conducted continuously through the approach of affirmation-suggestion and positive self-hypnosis, which is one form of counseling and therapy that can be done to restore the emotional state of prisoners to be in a good and positive point. The training is intended to strengthen the heart and arranged to keep the human nature in balance towards taqarrub and submission to Allah swt. The goal is to form a human who has a personality with high quality and has an awareness of physical and emotional aspect.

Similar studies related to efforts to establish the mental and physical balance of the body also has a lot to do. Baskara, Soetjipto and Atamimi conduct research related to the practice of meditation. The research results show that regular meditation can change the individual becomes quieter. Individuals will react to emotional distress in a way that does not hurt either for himself or others. Meditation calms the mind and brings individuals on a clear understanding of where people feel connected to everyone and everything. Meditation is a process of pursuing inward journey. It enhances self-awareness to self-development positively and fosters a sense of individual self-awareness empathy for others (Baskara, Soetjipto, and Atamimi 2015).

Nurhidayah who conducts research related emotional connection with the increase in work. The results of his research found that self-awareness makes a meaningful contribution to help improve outcomes. Working days that passed without awareness can lead to boredom. Lack of motivation and a va- 
riety of other emotions adversely affect the performance, in this case nursing care provided to clients (Nurhidayah 2006). Kusumawati also conducted research on the therapeutic music named Attention Through Music (ATM) to do self-awareness. The research results conclude that ATM therapeutic music can improve self-awareness of children with emotional barriers. The appropriate ATM therapeutic music can raise the enthusiasm, mood, and joy of children with emotional barriers (Kusumawati 2013).

While a research by (Liwarti 2013), related to the correlation analysis with the spiritual experience psychological well-being prison occupants, showed a significant positive relationship between spiritual experience with psychological well-being on the occupants of prisons. The results are consistent with some theories stating that there is a connection to the spiritual experience of psychological well-being. (Elison, C. G; Fan 2008) discuss the daily spiritual experiences associated with psychological well-being and can reduce stress. Similar research was conducted by (Ryan, R. M; Deci 2001). The results of these studies states that spiritual experience is positively correlated with happiness and psychological well-being.

Based on the background of the issues and review of the previous studies, this research analyzes how to increase awareness of emotion and spirituality of the prisoners in Semarang through training of Emotional Spiritual Power (ESP). By using a mix-method and quasi-experimental design (QED) method, this study involved prisoners who have been trained through $E S P$, including terrorist prisoners, prisoners of corruption, and women prisoners. Respondents were selected in this study were prisoners at Lembaga Pemasyarakatan (Lapas) Kelas 1 Kedungpane Semarang and Lapas Kelas IIA Wanita Semarang with the number of terrorist prisoners as many as 20 people, convict cor- 
ruption as many as 58 people, and as many as 30 women prisoners. After the data was collected then analyzed using experiment analysis with $\mathrm{T}_{\text {tes }}$ and descriptive analysis, the enhancement of emotional and spiritual awareness after training ESP program can occur.

\section{Emotional Spiritual Power (ESP)}

As described previously that in order to overcome the problem of stress and depression experienced by the prisoners, it is necessary to increase positive emotions and spirituality within the prisoners. This step requires a systematic manner and is measured to find the balance of the soul. One of the steps that can be taken is the ESP training program that aims to raise awareness of emotional, spiritual, and thought patterns to change the attitude towards positive social skills.

The ESP training program is carried out in the form of training directed to control the "disruption of the body's energy system" and eliminate negative emotions. ESP training program is conducted to control the memory not to break up the memory of a traumatic past. In other words, the ESP training program is a "short cut" to break the chain of human disturbance or negative emotions. How this is done by keeping the body's energy balance system that consists of the balance of the soul and the body's chemical balance through affirmative action, such as positive suggestion, self-hypnosis, meditation, and action against self-therapy. The end result is that neutralize the negative energy into positive energy.

Thus, the ESP training program is one alternative to address stress and depression, because it is intended as a process to strengthen the human nature in balance towards taqarrub and submission to Allah. Basically, this kind of learning process can be done autodidactly with guidance made by professionals. But for beginners, autodidact learning is still vulnerable and it even 
tends to be prohibited because of misleading effect to a person. Examples in the practices of religious behavior proved numerous cases of religious behavior strange and tend to move out of the law is correct. It includes about forms of organizing training heart like ESP training program.

Theoretically, according to (Scherer 2005), the program involves emotion subsystems in the organism's body, including the central nervous system, neural-endocrine system, autonomic nervous system and the somatic nervous system. The emergence of positive emotions such as gratitude and appreciation has associated with high coherence in heart rhythm patterns. This indicates a shift in the balance of the autonomic nervous system is further improved in parasympathetic nerve activity. When someone uses a variety of ways to create or strengthen a sense of gratitude and appreciation, heart rhythm coherence is significantly increased, so did the ratio of alpha wave rhythm synchronized to the heart. The percentage of alpha waves are synchronized to increase significantly in the left hemisphere in most parts of the temporal lobe.

Raising awareness of emotional and spiritual prisoners with ESP training program is a technique that can connect the amygdala, limbic and neocortical which is an area of cooperation or struggle for influence made by the head and the heart, reason and feeling. That is why this circuit relationship explains why the role of emotion is so important for effective reasoning, both in making decisions - a wise decision and allow the prisoners to think clearly. Antonia Damasio, a neurology expert at the University of Iowa, College of Medicine, in his writing about the broad implications for understanding the mental life has done a profound study on whether actually defective in patients with damage to the prefrontal-amygdala circuit. Decision-making system turns severely disabled, and surprisingly, a person does 
not show his decrease in IQ or cognitive ability. Although a person's intelligence is intact, a person make decisions that cause problems in business and personal life, and can even be continuously confused about a decision that is very simple, such as when making an appointment (Junaidi 2006).

ESP is a training to develop the conscience on the prisoners, so prisoners were able to use his voice. Excessive impetus to achieve something that is desired, such as wealth, status and honor. Ignoring the balance of the legal requirements of the Lord will only result in failure proved even a collapse. The urge to be the largest, regardless of other factors will cause the entire system to be disrupted, and ultimately will reap destruction. The brain is capable of making any reason logically and make sense, including a matter of logic on paper, so that anyone can be defeated argumentative. However, conscience will never lie. He was very honest to tell the truth, because she is a reflection of the nature of God the Most True (Agustian 2005).

\section{Implementation of ESP Steps}

In order to achieve the expected results, the implementation of a ESP training program requires systematic and measurable steps consisting of preliminary activities, implementation, and evaluation. The three steps are as follows:

First, preliminary activities. These activities carried out with the involvement of all prisoners, including convict terrorists, corruption prisoners, and female prisoners in ESP activities. The preliminary activities began with a prayer together and introduction about what and how ESP is done and its benefits in building positive emotions and spirituality with full sincerity.

Second, implementation activities. The implementation of ESP training program to the prisoners is carried out in several stages as follows: 
a. Neuro Linguistic Programming (NLP)

In this NLP activities, prisoners are required to perform the Set-Up, Tune-In, and Tapping. These three steps are called reframing and anchoring. That is, when the prisoners perform a second and third step, the Tune-In and "Tapping", basically the prisoners were doing "Breaking the Pattern". In these activities, the prisoners imagine the problem coupled with a sincere and submissive heart.

b. Self-Hypnotherapy $(\mathrm{SH})$

In this $\mathrm{SH}$ activity, prisoners are encouraged to do hypnosis to themselves to erase the subconscious programs that can cause negative emotions by building self-suggestion or affirmation.

c. Visualization

After self-hypnosis, then the prisoners were asked to visualize against each other's experiences. This is important because in general, the human brain cannot distinguish the true experience from the experience that can only be imagined. This technique aims to mobilize the human potentials that are very useful to heal negative emotions and spirituality and then to be filled with consciousness and sincerity values.

d. Meditation (Grounding)

Meditation is a spiritual practice that is taught by most religions, not limited to Hinduism and Buddhism. Although the meditation is practized in different ways, but it is essentially the same. In the Christian tradition, meditation is known as retret or silent moments. Jews, in the other hand, call it a sabbatical days. Likewise, Islam call it as dhikr, tafakkur, or tawajiuh, such as șalat or prayer which is actually a form of meditation accompanied by the inhibition movements to Allah. In this sense, the ESP training program is a kind of meditation practice that brings prisoners to enter to a state of calm and relaxing, feeling the breath, and being aware of the presence of God in him. These 
all are believed to be able to direct the prisoners to get back to their true self-identity. Therefore, the ESP training program that is used is a simple meditation.

Third, evaluation activities. The evaluation is done by providing instruments to prisoners who followed the ESP training program, and then by monitoring their daily activities. This is necessary so that the program can see how far the changes in emotional, spiritual, and behavioral aspects of the prisoners are made.

There are three key factors that affect the success of ESP program when dealing with the emotional and spiritual improvement. The three must exist in the implementation process of the ESP training program, i.e. from set-up, tune-in, and tapping. The three keys to success are as follows:

First, khushu' or concentration. During the ESP training program, especially during set-up, the inmate must do total concentration or khushu', the situation of which is found at the time of prayer to God Almighty with full humility. One of the causes of why a prayer is not accepted by God is because the prisoners do not show khushu'; their hearts and minds were not present when praying. Therefore, they should do total concentration and eliminate other thoughts. The prisoners must concentrate on words that were spoken during the set-up.

Second, sincerity. Besides khushu', at the time of the ESP training program, prisoners should also have sincere feelings or blessing, which receive the gift that has been given (either physical or emotional) with all your heart, do not complain, do not complain for the calamity that is being received. This is important because it makes prisoners have negative emotions and bad spirituality because of the unwillingness to accept the current condition. With sincere feelings, the prisoners can purify themselves from sins and mistakes that have been done. The more 
prisoners are revolted, then the problem will be more severe. Likewise, the more willingness they accept it, it is increasingly felt light, and even be quickly lost. Therefore, prisoners need sincerity, so that negative emotion will be lost. Even if the problem does not disappear then at least in his heart appeared sincere feeling that the problems as part of efforts to improve themselves.

Third, surrender. The sense of resignation is also important owned by the prisoners at the time of the ESP training program. Surrender is different from sincerity. It is to hand whatever happens to someone's life to God. Whatever comes after the prisoners' surrender, they must surrender completely to God Almighty. By having a surrender, a prisoner will feel the peace of mind and peace of mind because he believes that all existing problems within his grasp. However, surrender does not mean inactiveness; it is a state of mind to surrender completely to God, of course, coupled with the fighting spirit and unyielding efforts.

\section{Results of the Experiment}

Based on ESP training program conducted on prisoners, including convicts corruption, terrorist prisoners, and female prisoners in this study, then the resulting increase in emotional and spiritual, measured quantitatively using Ttes calculation. Based on the test results of the calculation, variables of emotional and spiritual awareness between control and experimental groups to prisoners who have acquired ESP training program is calculated as follows:

First, for the corruption prisoners, the variable of emotion obtains the average result for the control group $\bar{x}_{1}=64.93$, and the average results for the experimental group $\bar{x}_{2}=71.81$ with $n_{1}=29$ and $n_{2}=29$ obtained $\mathrm{T}_{\text {bitung }}=2.726$. In the other hand, the variable of spirituality obtains an average result for the control group $\bar{x}_{1}=95.04$, and the average result for the ex- 
perimental group $\bar{x}_{2}=104.81$ with $n_{2}=29$ and $n_{2}=29$ obtained $\mathrm{T}_{\text {bitung }}=3.265$. Thus, it can be concluded that there is increased awareness of emotion and spirituality within the prisoners. This means that prisoners who attended the ESP training program has an average level of emotional and spiritual awareness better than the untrained prisoners.

Second, for the terrorists prisoners, the variable of emotion obtains the average result for the control group $\bar{x}_{1}=65.30$, and the average results for the experimental group $\bar{x}_{2}=80.20$ with $n_{2}=10$ and $n_{2}=10$ obtained $\mathrm{T}_{\text {bitung }}=2.871$. In the other hand, the variable of spirituality obtains the average result for the control group $\bar{x}_{1}=91$, and the average result for the experimental group $\bar{x}_{2}=108.1$ with $n_{2}=10$ and $n_{2}=10$ obtained $\mathrm{T}_{\text {bitung }}=$ 2.461. Thus, there is an increase in emotion and spiritual awareness within the prisoners. This means that prisoners who attended the ESP training program has an average level of emotional awareness and spirituality better than the untrained prisoners.

Third, for the women prisoners, the variable of emotion obtains the average result for the control group $\bar{x}_{1}=90.6$, and the average result for the experimental group $\bar{x}_{2}=102.67$ with $n_{2}$ $=15$ and $n_{2}=15$ obtained $\mathrm{T}_{\text {bitung }}=3.080$. In the other hand, the variable of spirituality obtained the average result for the control group $\bar{x}_{1}=69.20$, and the average result for the experimental group $\bar{x}_{2}=80.33$ with $n_{2}=15$ and $n_{2}=15$ obtained $\mathrm{T}_{\text {bitung }}=$ 2.470. Therefore, there is an increased awareness of spirituality and emotion within the prisoners. This means that prisoners who attended the ESP training program have an average level of emotional awareness and spirituality better than the untrained prisoners.

Regarding the increased emotion, prisoners who have an ESP training program are generally able to develop a more positive way of thinking in the face of stress and depression problems and when interacting with others. One of the figures ter- 
rorist prisoners with initial IB or AT is highly respected by the group when interviewed stated that the ESP training program is very rational and able to manage the hearts of the participants. The program can give more positive thinking in their personal and social life. Consequently, they are able to think logically, to think positively, and act in a positive conscience, patience, resignation in every action. They are not easy to get angry, act more thoroughly, and avoid the concept of terrorism after thinking and contemplating by the power of the heart. ${ }^{2}$

The same thing was also conveyed by one of the prisoners corruption with the initials MT stating that a ESP training program conducted at the Institute of correctional Class I Kedungpane Semarang, able to develop the mindset of prisoners of conscious life is not just based on emotion or passion alone, but furthermore lives by thinking long, positive emotions to people and act through the day so that the prohibited act of religion and society can be avoided with a positive mindset and heart clear, rise from adversity, not with emotion and want to be happy through laying up treasure because it is a false happiness which arises through unconscious emotions. ${ }^{3}$

Regarding the increased spirituality, prisoners who have an ESP training program are generally able to develop a spirituality that truly departs from the heart, consciousness, and sincerity that reflect spirituality in everyday life. One terrorist figure with the initials IB alias AT when interviewed stated that the ESP training program is able to develop a spirituality. It is a real increased spirituality, not a false spirituality that considers oneself the most correct. ${ }^{4}$

\footnotetext{
${ }^{2}$ Interview with terrorist inmates with initials IB / initials alias AT on 10 November 2017

${ }^{3}$ Interviews with inmates corruption by the initials MT, on 16 November 2017

${ }^{4}$ Interview with terrorist inmates with initials IB / initials alias AT on 10 November 2017
} 
One female prisoner with the initials KM also stated that this training has made her a more sincere in life and feel every life must be connected to God with full submission. The process of life must be in accordance with the signs of religious and done with sincerity so as to avoid crime. ${ }^{5}$

Training ESP undertaken at the Lapas I Kedungpane Semarang Class IIA Women Semarang through the stages of the process of neuro linguistic programming, self-hypnotherapy, visualization, and meditation and remembrance lead prisoners to educate the heart and a positive mindset that is able to develop a spirituality of prisoners in the end will have an effect on other factors ranging from daily life, work, community, and other routine activities of life were able to make the prisoners received the ultimate happiness.

Thus, the ESP training program has clearly proven to be a reliable instrument to increase emotional and spiritual awareness of prisoners who followed the training program. Positive changes can make the prisoners being personally close to Allah, not only in the minds and hearts but also on the level of everyday life.

\section{Conclusion}

Based on the results and discussion above, this study concludes that the prisoners' emotion and spirituality have improved or changed into a better way after they join the ESP training program. The program is able to make them personally close to Allah, both in the mind, heart, and behavior of everyday life, so that all heart disease including stress and depression can be cured. The ESP training program give prisoner's series of training that cannot be done only with stimulants, but a contin-

${ }^{5}$ Interviews with female inmates with the initials KM, on 24 November 2017 
uous therapy by developing their emotional and spiritual power. Therefore, this ESP program can be used as a strategy to neutralize the negative energy and enhance the positive energy through the increased emotional and spiritual potentials of the prisoners. This is done in order to create new positive personal character. Positive energy is then activated and become a pattern in everyday life, a mindset. Therefore, after the prisoners go out of the prisons, they would be a fun person with akblaq al-karimah in the middle of society.

\section{Bibliography}

Agustian, Ary Ginanjar. 2005. Rahasia Sukses Membangun Kecerdasan Emosi Dan Spiritual ESQ Emotional Spiritual Quotient, The ESQ Way 1651 Ihsan 6 Rukun Iman Dan 5 Rukun Islam. Jakarta: Arga.

Baskara, Adya, H.P Soetjipto, and Nuryati Atamimi. 2015. "Kecerdasan Emosi Ditinjau Dari Keikutsertaan Dalam Program Meditasi.” Jurnal Psikologi 35 (02).

Elison, C. G; Fan, D. 2008. "Daily Spiritual Experiences and Psychological Well-Being among US Adults." Social Indicators Research 88 (02).

Junaidi, Iskandar. 2006. The Power of Soul for Great Health: Cara Menjadi Sehat Dan Bahagia Melalui Keseimbangan Fisik Dan Mental. Jakarta: Gramedia Pustaka Utama.

Kusumawati, Rina. 2013. "Keefektifan Penerapan Attention Through Music (ATM) Untuk Mengembangkan Kesadaran Diri (Self Awareness) Anak Dengan Hambatan Emosi.” Bandung: Universitas Pendidikan Indonesia.

Liwarti. 2013. "Hubungan Pengalaman Spiritual Dengan Psychological Well Being Pada Penghuni Lembaga Pemasyarakatan." Jurnal Sains Dan Praktik Psikologi 01 (01). 
Nurhidayah, Rika Endah. 2006. "Pentingnya Kecerdasan Emosional Bagi Perawat.” Jurnal Keperawatan Rufaidah Sumatera Utara 02 (01).

Nurulaen, Yuyun. 2012. Lembaga Pemasyarakatan, Masalah Dan Solusi: Perspektif Sosiologi Islam. Bandung: MARJA.

Ryan, R. M; Deci, E.L. 2001. "A Review of Research On Hedonic and Eudaimonic Well-Being." Happiness and Human Potentials 52 (02).

Scherer, K. R. 2005. "What Are Emotions: And How Can They Be Measured." Social Science Information 44 (04).

Syukur, Amin, and Fathimah Usman. 2009. Terapi Hati Dalam Pelatihan Menata Hati. Semarang: Pustaka Nuun. 